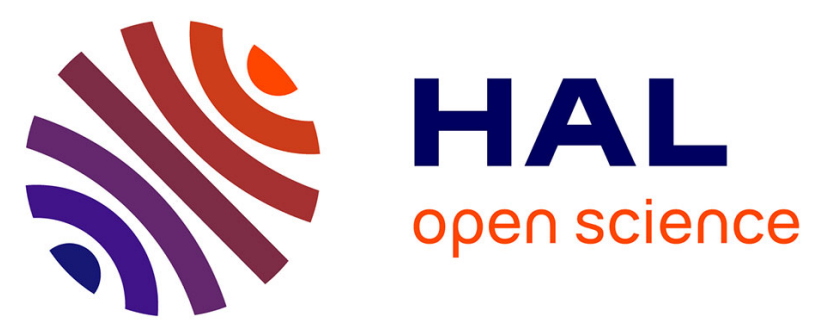

\title{
Marine diatom Navicula jeffreyi: from biochemical composition and physico-chemical surface properties to understanding the first step of benthic biofilm formation
}

Géraldine Klein, Guillaume Pierre, Marie-Noëlle Bellon-Fontaine, Jean-Michel Zhao, Martine Breret, Thierry Maugard, Marianne Graber

\section{To cite this version:}

Géraldine Klein, Guillaume Pierre, Marie-Noëlle Bellon-Fontaine, Jean-Michel Zhao, Martine Breret, et al.. Marine diatom Navicula jeffreyi: from biochemical composition and physico-chemical surface properties to understanding the first step of benthic biofilm formation. Journal of Adhesion Science and Technology, 2014, 28 (17), pp.1739-1753. 10.1080/01694243.2014.920461 . hal-01070418

\author{
HAL Id: hal-01070418 \\ https://hal.science/hal-01070418
}

Submitted on 8 Oct 2014

HAL is a multi-disciplinary open access archive for the deposit and dissemination of scientific research documents, whether they are published or not. The documents may come from teaching and research institutions in France or abroad, or from public or private research centers.
L'archive ouverte pluridisciplinaire HAL, est destinée au dépôt et à la diffusion de documents scientifiques de niveau recherche, publiés ou non, émanant des établissements d'enseignement et de recherche français ou étrangers, des laboratoires publics ou privés. 
1 Marine diatom Navicula jeffreyi: from biochemical composition and

2 physico-chemical surface properties to understanding the first step of

3 benthic biofilm formation

4

Géraldine L Klein $\ddagger^{\text {a }}$, UMR 7266 CNRS - LIENSs - Université de La Rochelle, Bâtiment

6 Marie Curie, avenue Michel Crépeau, 17042 La Rochelle, France.

7 Guillaume Pierreł ${ }^{\text {b }}$, UMR 7266 CNRS - LIENSs - Université de La Rochelle, Bâtiment

8 Marie Curie, avenue Michel Crépeau, 17042 La Rochelle, France.

9 Marie-Noëlle Bellon-Fontaine, UMR 0763 - MICALIS - Agro-ParisTech-INRA, 25 avenue 10 de la république, 91300 Massy, France.

11 Jean-Michel Zhao, UMR 7266 CNRS - LIENSs - Université de La Rochelle, Bâtiment Marie

12 Curie, avenue Michel Crépeau, 17042 La Rochelle, France.

13 Martine Breret, UMR 7266 CNRS - LIENSs - Université de La Rochelle, Bâtiment Marie

14 Curie, avenue Michel Crépeau, 17042 La Rochelle, France.

Thierry Maugard, UMR 7266 CNRS - LIENSs - Université de La Rochelle, Bâtiment Marie

Curie, avenue Michel Crépeau, 17042 La Rochelle, France.

Marianne Graber ${ }^{*}$ UMR 7266 CNRS - LIENSs - Université de La Rochelle, Bâtiment Marie Curie, avenue Michel Crépeau, 17042 La Rochelle, France.

‡ G.L.Klein and G.Pierre equally contributed to this work.

*Corresponding author, Tel: (33) $5464586 \quad 30 \quad$ Fax: (33) 546458265 E-mail: mgraber@univ-lr.fr

${ }^{a}$ present affiliation : CEA - Saclay, DSV/IBiTeC-S/SBIGEM - Bat. 142, 91191 Gif-surYvette, France

${ }^{\mathrm{b}}$ present affiliation : Polytech Clermont-Ferrand - Département Génie Biologique - 24 Avenue des Landais, BP20106 - 63174 Aubière CEDEX 1, France 


\section{Abstract}

To understand the first step of marine benthic microbial mat formation and biofouling phenomena, caused by diatoms in the marine environment, the surface properties of the epipelic diatom Navicula jeffreyi were studied and the composition of its bound Extracellular Polymeric Substances (EPS) was determined. These parameters are determining factors for the initial adhesion step of diatoms to other constituents that start marine fouling. Surface energy of a diatom cell layer was determined using the sessile drop technique and highlights that diatoms show a moderate hydrophobic character (contact angle with water $>68^{\circ}$ ), no Lewis acid character $\left(\gamma^{+}<1 \mathrm{~mJ} / \mathrm{m}^{2}\right)$ and a low Lewis basic character $\left(\gamma^{-}=16,1 \mathrm{~mJ} / \mathrm{m}^{2}\right)$. An extraction procedure using a cationic resin subtracted only the bound EPS. Biochemical assays showed that there were 2.5 times more proteins than sugars. The propensity of Navicula jeffreyi diatom to adhere to five different solid surfaces, showing a gradient in their hydrophobic and hydrophilic character, was measured. The attachment densities were high on hydrophobic surfaces such as polytetrafluoroethylene and very low on substrata with surface free energy over $40-50 \mathrm{~mJ} / \mathrm{m}^{2}$. Using a thermodynamic approach, the free energy of adhesion of the diatom to the five substrata was determined, and led to a very strong correlation with attachment densities for polytetrafluoroethylene, polyamide, polyethylene and stainless steel.

Keywords: Bioadhesion, Contact angle measurements, Diatom, Extracellular Polymeric Substances, Microalgae, Physico-chemical surface properties.

\section{Introduction}

Diatoms are the most common early autotrophic colonizers of surfaces in seawater and are an important constituent of the biofouling community in the marine environment, together with bacteria and other algae [1,2]. Diatoms form an ubiquitous group of unicellular microalgae characterized by their highly ornate, siliceous cell walls, associated with organic extracellular 
polymers [3]. Marine biofouling phenomena cause serious and costly problems for surfaces immersed in seawater, such as energy loss for boats, increased risk of mechanical failure for static marine structures as well as safety problems [4-7]. During their assemblage diatoms produce copious amounts of Extracellular Polymeric Substances (EPS), rich in proteins and carbohydrates $[8,9]$, which form an adhesive mucilage and allow them to build and, at a later stage, to hold the biofilm together [10]. EPS also permit the attachment of other fouling organisms, such as bacteria, to the sediment or to immersed solid surfaces [11]. These EPS are secreted from a slit in the cell wall called the raphe. A common feature of adhesion in raphid diatoms is that adhesive mucilages appear to be processed in several complex steps over time, and these depend on the stage of adhesion as well as the nature of both the organism and the substratum [12]. Most fouling diatoms have an initial adhesive mucilage that they use for traction and movement (initial mucilage) and then a more permanent adhesive mucilage when they eventually settle down to divide and form a biofilm (biofilm mucilage). There are also several distinct types of EPS; motility, outer capsule, and matrix EPS, that can all participate in the adhesion process [12]. The goal of the present paper is to study the transitory physicochemical interactions that occur between diatoms with initial mucilage and different substrata. In general, adhesion of microorganisms is influenced by environmental (temperature, $\mathrm{pH}$ and ionic strength), interfacial (surface charge and hydrophobic or hydrophilic character of the microbial cells, chemical composition) and physiological factors (type of microorganisms) [13-15]. The roughness, or the mechanical properties, of the substratum [16], as well as the roughness of the cell surface, can also influence the adhesion of cells to surfaces. Among the parameters outlined, interfacial properties can be most readily altered by using solid surfaces with coatings that prevent adhesion of microorganisms.

Interfacial properties are linked to the surface energy of both the microorganism cell surface and the solid substrate surfaces, that is a measure of the capacity of a surface to interact spontaneously with other materials by forming new bonds. While the effect of the surface 
energy of solid substrata on the adhesion strength of diatoms has often been studied by employing widely different materials, ranging from urethanes and epoxies (high surface energy), to silicones and fluorinated materials (low surface energy) [6,10,17-19], the measurement of the surface energy of diatom cells themselves has rarely been performed [20]. We feel that such measurements could help in understanding the first step of benthic biofilm formation, and thus help to prevent adhesion of microalgae to surfaces submerged by the sea. In this report, the first part is devoted to a study of the surface properties of the epipelic diatom Navicula jeffreyi, a diatom largely involved in the formation of microphytobenthic biofilms. The cell length, width, and volume of Navicula jeffreyi are respectively equal to $11.18 \pm 0.82 \mu \mathrm{m}, 7.56 \pm 0.60 \mu \mathrm{m}$ and $366.71 \pm 85.50 \mu \mathrm{m} 3 /$ cell $($ mean $\pm \mathrm{SE})(\mathrm{n}=6)[21]$ Diatom cells were grown on an orbital shaker, so that they do not form a biofilm, and then freeze-dried, in order to have diatoms with their initial mucilage only. The surface energy of the diatom was determined by applying the sessile drop technique to a cohesive layer of diatom cells resuspended in water and was calculated using the Lifshitz van der Waals acidbase (LW-AB) method. The second part of the report evaluates the propensity of these diatom cells to adhere to five different solid surfaces showing a gradient in their hydrophobic and hydrophilic character. The role of the initial EPS in adhesion was also investigated, in particular, by extracting the bound polymers and characterizing their biochemical composition. Finally the experimentally observed adhesion of $N$. jeffreyi diatom to the five different substrata was compared with that predicted by a thermodynamic approach that uses the calculation of the free energy of adhesion.

\section{Materials and Methods}

\subsection{Microalgal strain and growth conditions}

The N. jeffreyi strain (CS-46/8) was from CSIRO Marine and Atmospheric Research (Australia). $20 \mathrm{~mL}$ of F/2 liquid medium (Sigma-Aldrich) were suspended in 1L of Artificial 
Sea Water (ASW, Tropic Marin Sea Salts, Wartenberg, Germany, 30 Practical Salinity Units).

$106100 \mathrm{mg} / \mathrm{L}$ of sodium metasilicate were added to the medium then the $\mathrm{pH}$ was adjusted to 8.2.

107 This solution was used as growth medium for $N$. jeffreyi. Cells were grown on an orbital

108 shaker (50 rpm) and kept for 20 days at $18^{\circ} \mathrm{C}$, in conditions of natural alternating day/night.

109 After 20 days, corresponding to the end of the exponential growth phase, microalgal cells

110 were harvested by centrifugation for $10 \mathrm{~min}$ at $6000 \mathrm{~g}$ and $4{ }^{\circ} \mathrm{C}$ then washed twice with, and

111 resuspended in $\mathrm{NaCl} 0,9 \%$. Cells were then collected and resuspended in $10 \mathrm{~mL}$ of ASW

112 diluted 1: 1000. Finally, the suspensions were freeze-dried and stored at $4{ }^{\circ} \mathrm{C}$ until they were

113 used for the following experiments.

\subsection{Extraction of the Extracellular Polymeric Substances (EPS) bound to $N$. jeffreyi cells}

116 The extraction of EPS bound to N. jeffreyi cells was performed with Dowex resin, as this method was developed for culture pellets of $N$. jeffreyi cells and was shown to provoke the minimum release of internal compounds (protein, ATP) and the lowest proportions of glucose compared with the water-extracted EPS [22], from which the high glucose content must be

120 inferred as contamination by the chrysolaminaran found in the vacuoles of the diatoms [23].

$12120 \mathrm{~mL}$ of ASW were added to $30 \mathrm{mg}$ freeze-dried cells. $5 \mathrm{~g}$ of activated Dowex (Marathon C,

122 previously activated in Phosphate Buffer Saline for $1 \mathrm{~h}$ in the dark) were gently mixed with the sample at $4^{\circ} \mathrm{C}$ for $1 \mathrm{~h}$ in the dark. The solution was then centrifuged at $3500 \mathrm{~g}$ and $4^{\circ} \mathrm{C}$ for 10 min and the supernatant was collected, freeze-dried and stored at $-80^{\circ} \mathrm{C}$ prior to biochemical analysis.

\subsection{EPS composition}

128 Total sugar and protein content of EPS and also sugar composition of polysaccharidic fraction of EPS were determined by previously used methods for EPS from the Navicula genus of

130 diatoms [24-26]. Total sugar content was determined using the phenol-sulfuric acid assay, 
131 using glucose as standard [27]. Protein content was determined using the bicinchoninic acid

132 assay, using bovine serum albumin as standard [28]. The sulfate content was measured by the

133 Azure A assay [29], using dextran sulfate as standard.

134 The sugar composition of the bound EPS fraction was determined as follows. $N$. jeffreyi

135 bound EPS fraction was dissolved in $2 \mathrm{M} \mathrm{HCl}$ at $50 \mathrm{mg} / \mathrm{mL}$ and heated at $100^{\circ} \mathrm{C}$ for $20 \mathrm{~h}$.

136 Polysaccharides were completely hydrolyzed in monomers, then the preparation was freeze-

137 dried and stored at $-20^{\circ} \mathrm{C}$. Analysis of the carbohydrate fraction was carried out by GC/MS

138 using a Varian CP-3800 GC/Varian Saturn 2000. Operating conditions were based on the

139 methodology of Pierre [26]: $200 \mu \mathrm{L}$ of pyridine and $200 \mu \mathrm{L}$ of BSTFA(N,O-

140 bis(trimethylsilyl)trifluoroacetamide):TMCS(trimethylchlorosilane) (99:1) per $\mathrm{mg}$ of

141 hydrolyzed EPS were added. The solution was mixed for $2 \mathrm{~h}$ at room temperature and injected

142 into a DB-1701 J\&W Scientific column $(30 \mathrm{~m}, 0.32 \mathrm{~mm}, 1 \mu \mathrm{m})$. The helium pressure was 8.8

$143 \mathrm{psi}$ and the flow rate was $1 \mathrm{~mL} / \mathrm{min}$. The temperature of the injector was set at $250^{\circ} \mathrm{C}$. The

144 rise in temperature in the oven was programmed for a first step at $150^{\circ} \mathrm{C}$, then an increment of

$14510{ }^{\circ} \mathrm{C} / \mathrm{min}$ up to $200^{\circ} \mathrm{C}$ with a final step at $200^{\circ} \mathrm{C}$ for $35 \mathrm{~min}$. The ionization was performed

146 by Electronic Impact $(70 \mathrm{eV})$, the trap temperature was set at $150^{\circ} \mathrm{C}$, the transfer line

147 temperature was defined at $180^{\circ} \mathrm{C}$ and the target ion was fixed at $40-650 \mathrm{~m} / \mathrm{z}$.

148 In order to check that the freeze-drying step for the diatom cells did not have any influence on

149 this composition, the bound EPS extraction procedure was applied to diatoms cell with and

150 without freeze-drying and the monosaccharide composition of polysaccharides was

151 determined for both samples of bound EPS.

152

153 1.4 Determination of surface energy of substrata and diatom cells and the free energy of

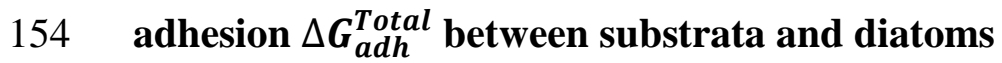

155 There are many thermodynamic approaches in the literature to evaluate the cells or solid

156 substrata surface energy. All of them are based on contact angle measurements with different 
157 liquids with known surface tension, which were shown to give reproducible and accurate

158 results for both inorganic material surfaces and microbial cell surfaces [30-32]. However the

159 values of calculated surface energy from contact angles measurements depends on the

160 followed approach: Fowkes, Equation of state, Geometric mean and Lifshitz van der Waals

161 acid-base (LW-AB) approaches. In 2002, a remarkable study was published about the surface

162 energy of 140 bacterial and 7 yeast cell surfaces, determined by the four different approaches

163 mentioned above [30]. LW- AB was found to give the most consistent results. That is why we

164 chose this last method to evaluate surface energy of the five different substrata and the

165 epipelic diatom $N$. jeffreyi.

166 Five solid materials at monolithic and film state were used. The roughness and porosity of all

167 these materials were considered as insignificant. Four materials were provided by

168 Goodfellow: Stainless Steel AISI 316L (0.5 mm thick, noted SS316), Polytetrafluoroethylene

169 (0.5 mm thick, noted PTFE), Polyamide-nylon 6 (0.5 mm thick, noted PA) and Polyethylene

170 (0.5 thick, noted PE), and Glass (1 mm thick microscope slides) was provided by Thermo.

171 The films were cut into $4 \mathrm{~cm}^{2}$ pieces and washed in $2 \%$ PCC-54 (v/v, phosphate-free

172 surfactant, Thermo Scientific) for 10 min then rinsed 5 times with sterile milliQ water.

173 The surface energy of $N$. jeffreyi was measured by producing a uniform and cohesive layer of

174 cells deposited on membrane filters [31]. The layer of cells was prepared by depositing $40 \mathrm{~mL}$

175 of microalga suspended in milliQ water (approximately $10^{10}$ cells $/ \mathrm{mL}$ ) on a cellulose

176 triacetate membrane filter (with a pore diameter of $0.45 \mu \mathrm{m}$, Sartorius) by filtration of the

177 suspension using low depression. The filters with the diatoms were then placed in a petri dish

178 on the surface of a layer of $1 \%$ agar $(\mathrm{w} / \mathrm{v})$ in water containing $10 \%(\mathrm{v} / \mathrm{v})$ glycerol to preserve

179 constant moisture content [32]. The filters were stored for $30 \mathrm{~min}$, at room temperature. Three

180 separate filters from three different cultures were used and the results were averaged. The

181 filters were then placed on empty Petri dish and allowed to air dry for 30 to 45 min $[31,32]$.

182 After this drying time, same contact angles were measured for water droplets deposited on the 
183 diatom layer several minutes apart, indicating that water evaporation from the layer was

184 achieved. The contact angle was consistent for $30 \mathrm{~min}$ up to $120 \mathrm{~min}$ of drying time.

185 The contact angle (CA) measurements were performed with a goniometer G40 (Krüss,

186 Germany) at room temperature $\left(23^{\circ} \mathrm{C}\right)$ with an accuracy of $\pm 2{ }^{\circ} \mathrm{C}$, employing the sessile drop

187 technique and using three pure solvents whose surface tension components were known

188 (Table 1): distilled water (Infilco), diiodomethane 99\% (Sigma-Aldrich) and formamide $\geq$

$18999 \%$ (Sigma-Aldrich). During measurements, each probe was dropped on the cell layer or the

190 solid surfaces, and CA were measured immediately for $10 \mathrm{~s}$. Left and right contact angles in at

191 least 3 locations were measured, with highest and lowest values discarded. The CA was

192 calculated as the average of these values. According to the LW-AB approach, CA were

193 converted into surface free energies using equation 1 (Eq.1) [33], which ignores spreading

194 pressure and highlights Lifshitz-van der Waals and Lewis acid/base surface free energy

195 components.

196

$$
\gamma_{L}^{t}(1+\cos \theta)=2\left(\sqrt{\gamma_{S}^{L W} \gamma_{L}^{L W}}+\sqrt{\gamma_{S}^{+} \gamma_{L}^{-}}+\sqrt{\gamma_{S}^{-} \gamma_{L}^{+}}\right)
$$

197 Here, $\gamma^{L W}, \gamma^{+}$and $\gamma^{-}$are the Lifshitz-van der Waals, electron-acceptor (or Lewis-acid) and

198 electron-donor (or Lewis-base) components of the surface free energy respectively; $\theta$ is the

199 CA and the subscripts L and S denote the liquid and solid samples.

200 Equation 2 allows accessing to the Lewis acid-base components of the surface free energy:

201

$$
\gamma^{A B}=2 \sqrt{\gamma^{+} \gamma^{-}}
$$

$202 \Delta G_{a d h}^{\text {Total }}$ is obtained by first determining the surface properties of micro-organisms and 203 substrata and the tension surface of the medium. Then, the total interfacial free energy of 204 microbial adhesion is determined by the triple relationship between the organism (NJ), the 205 substratum (S) and the liquid (L) [34,35]:

$$
\Delta G_{a d h}^{T o t a l}=\Delta G_{a d h}^{L W}+\Delta G_{a d h}^{A B}
$$




$$
\Delta G_{a d h}^{L W}=\left(\sqrt{\gamma_{N J}^{L W}}-\sqrt{\gamma_{S}^{L W}}\right)^{2}-\left(\sqrt{\gamma_{N J}^{L W}}-\sqrt{\gamma_{L}^{L W}}\right)^{2}-\left(\sqrt{\gamma_{S}^{L W}}-\sqrt{\gamma_{L}^{L W}}\right)^{2}
$$

$$
\begin{aligned}
& \Delta G_{a d h}^{A B}=2\left[\sqrt{\gamma_{L}^{+}}\left(\sqrt{\gamma_{N J}^{-}}+\sqrt{\gamma_{S}^{-}}-\sqrt{\gamma_{L}^{-}}\right)+\right. \\
& \left.\sqrt{\gamma_{L}^{-}}\left(\sqrt{\gamma_{N J}^{+}}+\sqrt{\gamma_{S}^{+}}-\sqrt{\gamma_{L}^{+}}\right)-\sqrt{\gamma_{N J}^{-} \gamma_{S}^{+}}-\sqrt{\gamma_{N J}^{+} \gamma_{S}^{-}}\right]
\end{aligned}
$$

\subsection{Microscopic analyses}

211 Scanning Electron Microscopy (SEM) was used to examine the aspect of the microalgal cells

212 after freeze drying. Samples were previously metallized by a layer of gold-palladium under

213 vacuum. SEM observations were made with a JEOL 5410 JV SEM in high vacuum mode, using $2.0 \mathrm{KV}$ as accelerating voltage.

\section{6 $N$. jeffreyi attachment densities measurements}

217 Lyophilized microalgae were re-suspended in ASW diluted 1:1000 to give a suspension of 218 cells with a chlorophyll content of approximately $0,3 \mu \mathrm{g} / \mathrm{mL}$ measured by fluorimetry with acetone $90 \%$. Five milliliters of cell suspension were carefully pipetted into a quadriPerm microwell plate (Sarstedt) containing three pieces of material $\left(4 \mathrm{~cm}^{2}\right)$ on the bottom. Two

221 series were produced. After a set of different periods of attachment (2, 3, 5.5, 18, 24 and 48 222 hours, and 3 and 4 days) with slow orbital agitation (20 rpm, Rotamax 120, Heidolph) in the 223 dark, the cell suspensions were carefully aspirated. Afterward, $5 \mathrm{ml}$ of ASW diluted 1/1000 was pipetted into each well followed by slow shake back and forth five times to remove unattached cells. After washing, all the coupons were dried under a laminar flow hood for $1 \mathrm{~h}$.

226 Attachment densities were obtained by counting the adhered cells using a fluorescence 227 microscope (Leica DMRB) combined with image software (Leica Application Suite v3.8). 
The Y5 filter set was used (excitation $620-660 \mathrm{~nm}$ ) and the $\lambda$ used for emission was 700-775 $\mathrm{nm}$. Counts were made for 20 fields $\left(0.16 \mathrm{~mm}^{2}\right)$ randomly taken on the surface on each of the three replicate coupons. Cell settlement data are expressed as the mean number of cells adhered per $\mathrm{mm}^{2}$. Each standard deviation is represented by error bars and calculated with raw data of three independent replicates.

\section{Results and discussion}

2.1 N. jeffreyi : from microscopic observations to biochemical and physico-chemical surface characterization

We used a freeze-drying treatment in this study because it allows the maintenance of microalga in a "fixed" state with initial mucilage. In the experiments presented here, this fixed state gives access to the initial step of attachment without having interference from polymeric metabolites (biofilm mucilage), which are synthesized when colonization occurs. The idea is to study the very early stage of attachment, that corresponds to a passive step, due to the net force of interaction between the diatom surface and the support that arises from the balance between van der Waals and Lewis acid-base forces. The diatoms are here considered as colloidal particles with bound initial adhesive polymers. It has to be kept in mind that these "living colloids", upon contact with a surface, will excrete supplementary adhesive polymers, allowing for strong adhesion to the surface and finally for irreversible biofilm formation. The ability of benthic diatoms to form biofilm is largely due to the secretion of these mucilaginous EPS from the raphe [12,36].

249 Scanning electromicroscopy (SEM) shows N. jeffreyi cells (Figure 1) with an intact structure, 250 indicating that freeze-drying does not damage microbial cell surfaces. The SEM also shows 251 the presence of EPS closely bound to the $N$. jeffreyi cells (Figure 1). The EPS detected by 252 SEM in our samples correspond to the bound initial adhesive polymers that are very important 253 mediators in the initial step of adhesion of diatoms to surfaces. 
254 In order to extract cell bound $N$. jeffreyi EPS a cationic resin was used. Extraction protocols 255 can distinguish a range of EPS types, depending on their degree of interaction with diatom 256 cells: (1) colloidal fractions, corresponding to the EPS excreted into the medium, (2) bound 257 fractions, corresponding to the EPS surrounding the cells and (3) residual fractions, 258 corresponding to the internal EPS [26]. Total sugar and protein content assays showed that the 259 bound EPS had 2.5 times more proteins than sugars. Sulfated sugars were not detected. This 260 composition is consistent with the works of various authors who have shown that adhesive EPS are composed of cross-linking proteins (probably glycoproteins), polysaccharides and phenols with covalent o-linkages [37,38]. These surface polymers are directly involved in the physico-chemical surface properties of microorganisms.

264 The monosaccharide composition of the polysaccharidic fraction of bound EPS from $N$. 265 jeffreyi was also determined. In order to check that the freeze-drying step used to fix the 266 diatom cells did not have any influence on this composition, the bound EPS extraction 267 procedure was applied to diatom cells with and without freeze-drying and the monosaccharide composition of polysaccharides was determined for both samples. The results were very 269 similar whether or not the diatoms had undergone freeze-drying (Table 2). The 270 monosaccharidic composition (expressed in $\% \mathrm{w} / \mathrm{w}$ ) was $17 \%$ of galacturonic acid, $0 \%$ of 271 sulfated sugars and $83 \%$ of neutral carbohydrate. The neutral monosaccharidic composition 272 was dominated by glucose (36.1\% of the total fraction) but contained other sugars such as 273 rhamnose $(8.9 \%)$, mannose $(18.4 \%)$ and galactose $(19.5 \%)$. This composition is similar to 274 the one described for two other benthic diatoms, Cylindrotheca closterium and Navicula 275 salinarum [38].

276 We then characterized the surface energy of $N$. jeffreyi cells using contact angle (CA) 277 measurements.

278 Diatom layers were prepared by filtering their suspensions (c.f. Materials and Methods), in a 279 way that the cells covered the filter surface homogeneously and formed a cohesive layer. 
The measured CA from $N$. jeffreyi layers are detailed in Table 3. Based on these CA

281 measurements, equations 1 and 2 allowed the determination of the surface energy components 282 of filter alone and of N. jeffreyi cells (Table 4). Results show that there are significant differences between the data obtained with the membrane filter alone (controls) and those measured with the $N$. jeffreyi layers deposited on the same membrane, for the different individual surface energy components: $\gamma^{t}, \gamma^{-}$and $\gamma^{+}$. The CA of water with the $N$. jeffreyi layers $\left(68.6^{\circ}\right)$ shows that the microalgae surface, in general, is moderately hydrophobic.

The layer of diatoms presented a $\gamma^{\mathrm{t}}$ value equal to $36.7 \mathrm{~mJ} / \mathrm{m}^{2}$, a $\gamma^{\mathrm{LW}}$ value equal to 31.8 $\mathrm{mJ} / \mathrm{m}^{2}$ and a $\gamma^{\mathrm{AB}}$ value equal to $4.8 \mathrm{~mJ} / \mathrm{m}^{2}$. It showed no Lewis acid character $\left(\gamma^{+}<1 \mathrm{~mJ} / \mathrm{m}^{2}\right)$ and an average Lewis basic character $\left(\gamma^{-}=16.1 \mathrm{~mJ} / \mathrm{m}^{2}\right)$. The predominance of the electrondonor character is an indication of the nature of the chemical groups exposed at the surface of diatoms. Indeed, Lewis basic character is often attributed to neutral or slightly charged basic chemical groups such as carboxylate $\left(\mathrm{COO}^{-}\right)$, amine $\left(\mathrm{NH}_{2}\right)$, phosphate $\left(\mathrm{PO}_{4}^{-}\right)$groups of phospholipids or lipoproteins [39,40].

In the case of $N$. jeffreyi, the Lewis basic character of the diatom surface may derive, in part, from galacturonic acid and proteins in bound EPS.

In conclusion, the results of this first part demonstrate that the diatom cells of $N$. jeffreyi are moderately hydrophobic and also show an average Lewis basic character. In the second part, we demonstrate that these surface properties are linked to the propensity of the diatom to adhere to different solid surfaces, presenting a gradient in hydrophobic and hydrophilic 300 character. substrata

304 Prior to carrying out initial bioadhesion measurements, an optimization of the method for 305 diatom attachment measurement was carried out. The highest densities of attached cells were 
reached between 24-48h periods and then remained almost constant, as seen in Figure 2.

307 Furthermore, data showed no significant difference between a 24 h- and a 48 h-adhesion time and the spatial distribution of cells on the different surfaces was homogeneous until 48 hours of contact between cells and surfaces with very rare visible aggregates (no more than 10 cells stuck together). Thus a period of $24 \mathrm{~h}$ adhesion time in the dark was chosen. Cells were then counted after their adhesion to different surfaces (c.f. Materials and Methods and Table 4).

312 The initial affinity was calculated by means of the initial slope of each curve before $18 \mathrm{~h}$ attachment. N. jeffreyi adhered with a speed of 10 and 12 cell. $\mathrm{mm}^{-2} \cdot \mathrm{h}^{-1}$ on glass and polyamide-nylon (PA), respectively, and 77 and 78 cell. $\mathrm{mm}^{-2} \cdot \mathrm{h}^{-1}$ on stainless steel (SS316) and polyethylene (PE), respectively. Finally, N. jeffreyi adhered most quickly on 316 polytetrafluoroethylene (PTFE), with a speed of 121 cell. $\mathrm{mm}^{-2} \cdot \mathrm{h}^{-1}$.

317 To assess the effect of solid surfaces properties on the diatom-substratum interaction, physical 318 properties of the surfaces were measured. The surface energies, calculated from measured CA 319 (Table 3), of the five substrata used in this study are listed in Table 4. The obtained $\gamma^{\text {tot }}$ values 320 were in the range of $14.7-56.4 \mathrm{~mJ} / \mathrm{m}^{2}, \gamma^{\mathrm{LW}}$ in the range of $15.9-40.4 \mathrm{~mJ} / \mathrm{m}^{2}, \gamma^{+}$in the range of $3210.1-1.3 \mathrm{~mJ} / \mathrm{m}^{2}$, and $\gamma^{-}$in the range of $1.9-54 \mathrm{~mJ} / \mathrm{m}^{2}$. As expected, the results for the five 322 different surfaces showed reasonably good agreement with the literature data, within 323 experimental error [41]. The present data indicate that the five substrata form a gradient with decreasing surface hydrophobicity and increasing hydrophilicity. PTFE has the lowest $\gamma^{\text {tot }}$ and $\gamma^{\mathrm{LW}}$ values, equal to $17.1 \pm 0.9 \mathrm{~mJ} / \mathrm{m}^{2}$ and $15.9 \pm 0.6 \mathrm{~mJ} / \mathrm{m}^{2}$ respectively, and negligible $\gamma^{+}$and $\gamma^{-}$. Next, PE has a $\gamma^{\text {tot }}$ equal to $32.5 \pm 2.7 \mathrm{~mJ} / \mathrm{m}^{2}$, then, SS316 with $\gamma^{\text {tot }}$ of $40.6 \pm 0.4 \mathrm{~mJ} / \mathrm{m}^{2}, \mathrm{PA}$ with $\gamma^{\text {tot }}$ of $42.4 \pm 0.9 \mathrm{~mJ} / \mathrm{m}^{2}$ and glass with $\gamma^{\text {tot }}$ of $56.2 \pm 0.3 \mathrm{~mJ} / \mathrm{m}^{2}$.

To assess the influence of solid surface properties on the adhesion of diatom N. jeffreyi, the mean cell densities of attached cells on the five different solids were quantified. The 330 attachment densities of diatoms decreased with an increase in the total surface energy $\gamma^{\text {tot }}$ of 331 the substratum (Table 4). When $\gamma^{\text {tot }}$ is over $40 \mathrm{~mJ} / \mathrm{m}^{2}$, diatom adhesion is minimized. There 
were significant differences between attachment densities on the tested surfaces. The values

333 of attachment densities ranged from $2160 \pm 110$ cells $/ \mathrm{mm}^{2}$ at $17.1 \mathrm{~mJ} / \mathrm{m}^{2}$ to $225 \pm 29$ cells $/ \mathrm{mm}^{2}$ at $56.2 \mathrm{~mJ} / \mathrm{m}^{2}$ after $24 \mathrm{~h}$ attachment. The effect of the total surface energy on the adhesion of the diatom Navicula closterium MMDL533, using a series of more or less silanized glass slides as model surfaces, has been measured by other authors [34]. Our data profiles are similar to those of $\mathrm{Li}$ and co. [34] who examined initial attachment after 5.5h. We 338 confirm here the preference of $N$. jeffreyi for hydrophobic surfaces. In another earlier study, marine fouling diatoms Navicula perminuta were found to adhere 340 more strongly to hydrophobic surfaces than to hydrophilic surfaces. This behavior was ascribed to the physicochemical properties of their extracellular adhesives [14]. Navicula 342 perminuta cells were also shown to adhere more strongly to hydrophobic materials thanks the 343 hydrophobic segments of their EPS [42]. A similar conclusion was obtained for the diatom 344 Amphora [17], whose cells were found to attach more strongly to hydrophobic surfaces. 345 However, in another study, it was shown that Navicula diatom cells adhered with comparable 346 strength to a hydrophobic elastomer and a hydrophilic mineral [36]. This result was explained 347 by the presence of either different EPS macromolecules, different segments on these 348 macromolecules, or even different regions on the same macromolecule being likely to mediate 349 adhesion of Navicula sp. [36]. More generally, hydrophobic regions of adhesive exopolymers correspond to hydrophobic polypeptides and lipids, whereas hydrophilic regions correspond to hydrophilic saccharides on glycoproteins or polysaccharides [10]. In the case of $N$. jeffreyi, 352 bound EPS were found to include 2.5 times more proteins than sugars, which is in accordance 353 with the hydrophobic character of the diatom.

354 In general, diatom adhesion is weaker on hydrophilic surfaces when compared to hydrophobic surfaces $[6,17,42]$, in good agreement with the results obtained here.

356 The current study also addresses the question of whether the composition of EPS is similar 357 between initial and biofilm EPS for the same type of the diatom species and under the same 
growth conditions. Numerous studies have been carried out to evaluate the differences in

359 biochemical metabolites in planktonic and biofilm cells of bacteria [10,43]: differences

360 in carbohydrate profiles for EPS of planktonic and biofilm cells of marine diatom Amphora

361 rostrata, grown in batch culture, were highlighted. It has also been reported that, for some

362 diatoms, the adhesive properties of their EPS are unrelated to the amount of exopolymer

363 produced [10], suggesting that the chemical composition of EPS does not vary over time for a

364 particular type of diatom species grown under particular conditions. The results of the present

365 study confirm that diatom adhesion is strongest to hydrophobic surfaces. It should be noted

366 that the data obtained in this study used freeze-dried diatoms with initial mucilage after

367 passive attachment in the dark, while all other studies used diatoms with biofilm mucilage

368 after active settlement in the light. The data appears to suggest that the adhesive properties of

369 bound EPS remain constant between initial and biofilm EPS.

370 When considering the relationship between attached diatom cell density and the different

371 surface energy components of the five substrata (Table 4), it appears that the best correlations

372 are observed between cell density and van der Waals component, on the one hand, and

373 electron acceptor component on the other hand. In the case of the electron donor component, a

374 correlation was obtained between cell density and the four substrata PTFE, PA, PE and SS316

375 (the point corresponding to the glass substratum was not aligned with the others).

376 Finally, we tested whether it is possible to predict how a diatom can adhere to a substratum by

377 calculating the free energy of adhesion between the microalgae and the solid surfaces.

378 We used a Lifshitz van der Waals acid-base (LW-AB; [30]) thermodynamic approach to

379 determine the free energy of adhesion $\Delta G_{a d h}^{\text {Total }}$ of $N$. jeffreyi to the five different support

380 materials (c.f. Materials and Methods). This parameter is of crucial importance and may allow

381 the prediction of the initial adhesion of microorganisms, as the adhesion process will be

382 favored if the process itself causes the thermodynamic function to decrease $\left(\Delta G_{a d h}^{\text {Total }}<0\right)$. 
Using equations (3), (4) and (5), the values of the total interfacial free energy of adhesion of

$384 N$. jeffreyi to the five studied substrata and its components $\left(\Delta G_{a d h}^{L W}\right.$ and $\left.\Delta G_{a d h}^{A B}\right)$ were calculated

385 and are presented in Figure 3. When considering the relationship between attached diatom cell

386 density and the different contributions of the free energies of adhesion to the five substrata, it

387 appears that the best correlations are observed between cell densities and $\Delta G_{\text {adh }}^{\text {Total }}$ on the one

388 hand (Fig. 3) and $\Delta G_{a d h}^{A B}$ on the other hand (Fig. 3), for all the substrata except for glass which

389 is not aligned with the others. In the case of $\Delta G_{a d h}^{L W}$, its contribution to $\Delta G_{a d h}^{T o t a l}$ is insignificant

390 (Fig. 3). The negative values of $\Delta G_{a d h}^{T o t a l}$ and $\Delta G_{a d h}^{A B}$ actually lead to a strong adhesion of $N$.

391 jeffreyi to PA, PE, PTFE and SS316 surfaces. The adhesion test reveals a close correlation

392 between the surface hydrophobicity and $\Delta G_{a d h}^{\text {Total }}$ and the attachment of $N$. jeffreyi: the more

393 hydrophobic the substratum is, the more strongly $N$. jeffreyi adheres. For glass, the positive

394 values of $\Delta G_{a d h}^{\text {Total }}$ and $\Delta G_{a d h}^{A B}$ unexpectedly correspond to a weak but significantly positive 395 adhesion of $N$. jeffreyi to the hydrophilic surface, at a similar level to PA, for which a $\Delta G_{a d h}^{\text {Total }}$

396 value equal to $-28 \mathrm{~mJ} / \mathrm{m}^{2}$ was calculated (Fig.3). This adhesion to glass may be due to 397 possible local attractive electrostatic interactions, which are not explicitly included in the 398 thermodynamic approach used in the present study.

399 Thus, the thermodynamic analysis for hydrophobic substrata such as PTFE, PA, PE and 400 SS316 gives a good prediction of initial diatom cell attachment. This thermodynamic model is 401 a potentially very interesting tool for predicting the initial adhesion of diatoms on all types of 402 hydrophobic or moderately hydrophobic surfaces.

\section{Conclusion}

405 In the present paper, the initial interaction between diatom cells and different substrata, with very different hydrophobic and hydrophilic surface properties was studied. Diatom cells were grown on a shaker so that they did not form a biofilm, and then freeze-dried, in order to have 
diatoms with their initial mucilage only. A chemical attraction occurred between these diatom

409 cells and the substrata, which was predicted by the free energy of adhesion between the two components. The free energy was calculated from the surface energy of both diatom cells and

411 surface substrata, using a thermodynamic approach. In general, the more hydrophobic the 412 surface, the more strongly $N$. jeffreyi adheres to it. We observed very weak attachment to 413 surfaces with a total surface energy superior to $42 \mathrm{~mJ} / \mathrm{m}^{2}$. This paper constitutes an original 414 study of the transitory physico-chemical attraction between diatom cells containing bound 415 initial EPS and the substratum. This leads to an initial contact between the two components, 416 which was called "the first kiss" by Wetherbee and represents "an active commitment by 417 raphid diatoms to attach and activates adhesion mechanisms specifically designed for 418 subsequent binding to the substratum" [12]. One previous study about physico-chemical surface 419 properties of microalgae has been performed in 2013 [20] and showed interesting correlations 420 between surface properties and the cell-cell interactions, estimated by their propensity to form 421 colonies. The present study provides information for a better knowledge of cell-surface 422 interaction for a particular species of diatom. Both cell-cell and cell-surface interactions are 423 very important parameters for diverse biotechnological applications including algal biomass 424 production and marine biofouling prevention.

\section{Competing interests}

427 The authors declare that they have no competing interests.

\section{Author's contributions}

430 GLK conducted supports and diatom surface energy measurements, diatom adhesion 431 measurements, SEM observations and IR measurements, she drafted the manuscript, GP 432 carried out EPS extraction, sugar and protein assays and drafted the manuscript, MNBF 433 supervised supports and diatom surface energy measurements and revised the manuscript, 
434 JMZ carried out determination of sugar composition of bound EPS by GC/MS, MB is in 435 charge of diatom culture, TM supervised the bound EPS extraction and their subsequent 436 analysis, the study was coordinated by MG, who also contributed to the data analysis and 437 revised the manuscript.

\section{Acknowledgments}

440 This study was supported by the Conseil Général of Charentes-Maritime and the CPER 441 "Plateforme Littoral" sub-action "Valorisation Biotechnologique des ressources marines 442 littorales". The authors would like to thank T. Meylheuc for me microscopic observations and 443 J. Lavaud and B. Lebreton for helpful discussion about diatoms. The manuscript was 444 corrected by a native English speaking scientific translator (http ://traduction.lefevere445 laoide.net).

\section{References}

448 [1] Cooksey KE, Wigglesworth-Cooksey B. Adhesion of bacteria and diatoms to surfaces in 449 the sea: a review. Aquat Microb Ecol. 1995; 9:87-96.

[2] Patil JS, Anil AC. Biofilm diatom community structure: Influence of temporal and 452 substratum variability. 2005; Biofouling 21:189-206.

[3] Chiovitti A, Dugdale TM, Wetherbee R. Diatom adhesives: molecular and mechanical properties. In: Smith AM, Callow JA (eds) Biological adhesives. Springer-Verlag, Berlin; 4562006. 
461 [5] Kerr A, Cowling MJ, Beveridge CM, Smith MJ, Parr ACS. The early stages of marine 462 biofouling and its effect on two types of optical sensors. Environ Int 1998; 24:331-343.

463

464 [6] Holland R, Dugdale TM, Wetherbee R, Brennan AB, Finlay JA, Callow JA, Callow ME. 465 Adhesion and motility of fouling diatoms on a silicon elastomer. Biofouling 2004; 20:323466329.

467

468

[7] Sublette K, Peacock A, White D, Davis G, Ogles D, Cook D, Kolhatkar R, Beckmann D, 469 Yang X. Monitoring subsurface microbial ecology in a sulfate-amended gasolinecontaminated aquifer. Ground Water Monit R 2006; 26:70-78.

471

472 [8] Hoagland KD, Rosowski JR, Gretz MR, Roemer SC. Diatom extracellular polymeric 473 substances: function, fine structure, chemistry and physiology. J Phycol 1993; 29:537-556.

474

[9] Smith DJ, Underwood GJC. Exopolymers production by intertidal epipelic diatoms. Limnol Oceanogr 1998; 43:1578-1591.

[10] Becker K. Exopolysaccharide production and attachment strength of bacteria and diatoms on substrates with different surface tension. Microb Ecol 1996; 32:23-33.

481 [11] Wang Y, Lu J, Mollet JC, Gretz MR, Hoagland KD. Extracellular matrix assembly in 482 diatoms (Bacillariophyceae). II. 2,6-dichloro-benzonitrile inhibition of motility and stalk production in Achnanthes longipes. Plant Physiol 1997; 113:1071-1080. 
485 [12] Wetherbee R, Lind JL, Burke J, Quatrano RS. The first kiss: establishment and control of 486 initial adhesion by raphid diatoms. J Phycol 1998; 34:9-15.

[13] Underwood GJC, Boulcott M, Raines CA. Environmental effects on exopolymer 489 production by marine benthic diatoms: dynamics, changes in composition, and pathways of 490 production. J Phycol 2004; 40:293-304.

[14] Krishnan S, Wang N, Ober CK, Finlay JA, Callow ME, Callow JA, Hexemer A, Sohn

KE, Kramer EJ, Fisher DA. Comparison of the fouling release properties of hydrophobic fluorinated and hydrophilic PEGylated block copolymer surfaces: attachment strength of the diatom Navicula and the green alga Ulva. Biomacromolecules 2006; 7:1449-1462.

[15] de Kerchove AJ, Elimelech M. Calcium and magnesium cations enhance the adhesion of motile and nonmotile Pseudomonas aeruginosa on alginate films. Langmuir 2008; 24:33923399.

[16] Walker GC, Sun Y, Guo S, Finlay JA, Callow ME, Callow JASurface Mechanical Properties of the Spore Adhesive of the Green Alga Ulva. J Adhes 2005; 81:1101-1118.

[17] Finlay JA, Callow ME, Ista LK, Lopez GP, Calow JA. The influence of surface wettability on the adhesion strength of settled spores of the green alga Enteromorpha and the diatom Amphora. Integr Comp Biol 2002; 42: 1116-1122. 
511 [19] Wu AHF, Nakanishi K, Cho KL, Lamb R. Diatom attachment inhibition; limiting surface

512 accessibility through air entrapment. Biointerphases 2013; 8:5.

513

514 [20] Ozkan A. and Berberoglu H. Physico-chemical surface properties of microalgae. Colloid $515 \quad$ Surfaces B 2013; 112:287-293.

516

517 [21] Parker F., Davidson M., Freeman K., Hair S., Daume S. Investigation of optimal 518 temperature and light conditions for three benthic diatoms and their suitability to commercial scale nursery culture of abalone (Haliotis lavigata). J Shellfish Res 2007; 26: 751-761.

[22] Takahashi E, Ledauphin J, Goux D, Orvain F. Optimising extraction of extracellular polymeric substances (EPS) from benthic diatoms: comparison of the efficiency of six EPS extraction methods. Mar Freshwater Res 2013; 60:1201-1210.

[23] Chiovitti A, Molino P, Crawford SA, Teng RW, Spurck T, Wetherbee R. The glucans extracted with warm water from diatoms are mainly derived from intracellular chrysolaminaran and not extracellular polysaccharides. Eur J Phycol 2004; 39:117-128.

[24] Bellinger BJ, Abdullahi AS, Gretz MR, Underwood GJC. Biofilm polymers: relationship between carbohydrate biopolymers from estuarine mudflats and unialgal cultures of benthic diatoms. Aquat Microb Ecol 2005; 38:169-180.

[25] Pierre G, Graber M, Orvain F, Dupuy C, Maugard TBiochemical characterization of extracellular polymeric substances extracted from an intertidal mudflat using a cation exchange resin. Biochem Syst Ecol 2010; 38:917-923. 
538 Biochemical composition and changes of Extracellular Polysaccharides (ECPS) produced 539 during microphytobenthic biofilm development (Marennes-Oléron, France). Microbial Ecol $540 \quad 2012 ; 63: 157-169$.

542 [27] Dubois M, Gilles KA, Hamilton JK, Rebers PA, Smith F. Colorimetric method for 543 determination of sugars and related substances. Anal Biochem 1956; 150:76-85.

[28] Smith PK, Krohn RI, Hermanson GT, Mallia AK, Gartner FH, Provenzano MD, Fujimoto EK, Goeke NM, Olson BJ, Klenk DC. Measurement of protein using bicinchoninic 547 acid. Anal Biochem 1987; 150:76-85.

[29] Jaques LB, Ballieux RE, Dietrich CP, Kavanagh LW. A microelectrophoresis method for heparin. Can J Physiol Pharmacol 1968; 46:351-360.

[30] Sharma PK, Hanumantha Rao K. Analysis of different approaches for evaluation of surface energy of microbial cells by contact angle goniometry. Adv Colloid Interface Sci 2002; 98:341-463.

[31] van der Mei HC, de Vries J, Busscher HJ. X-ray photoelectron spectroscopy for the study of microbial cell surfaces. Surf Sci Rep 2000; 39:1-24.

559 [32] Busscher HJ, Weerkamp AH, van der Mei HC, van Pelt AWJ, de Jong HP, Arends J. 560 Measurement of the surface free energy of bacterial cell surfaces and its relevance for 561 adhesion. Appl Environ Microbiol 1984; 48:980-983. 
563 [33] van Oss JC, Chaudhury MK, Good RJ. Interfacial Lifshitz-van der Waals and polar 564 interactions in macroscopic systems, Chem Rev 1988; 88:927-941.

565

566 [34] Li Y, Gao YH, Yang JY, Que GH. Influence of surface free energy on the adhesion of 567 marine benthic diatom Nitzschia closterium MMDL533. Colloids Surf B 2010; 75:550-556.

569 [35] Bayoudh S, Othmane A, Bettaieb F, Bakhrouf A, Ben Ouada H, Ponsonnet L. 570 Quantification of the adhesion free energy between bacteria and hydrophobic and hydrophilic 571 substrata. Mater Sci Eng B 2006; 26: 300-305.

573 [36] Arce FT, Avci R, Beech IB, Cooksey KE, Wigglesworth-Cooksey B. A live bioprobe for 574 studying diatom-surface interactions. Biophys J 2004; 87:4284-4297.

575

576

[37] Wustman BA, Lind J, Wetherbee R, Gretz, MR. Extracellular Matrix Assembly in 577 Diatoms (Bacillariophyceae). III. Organization of Fucoglucuronogalactans within the 578 Adhesive Stalks of Achnanthes longipes. Plant Physiol 1998; 116:1431-1441.

580 [38] Stal LJ. Microphytobenthos, their extracellular polymeric substances, and the 581 morphogenesis of intertidal sediments. Geomicrobio J 2003; 20:463-478.

583 [39] Bellon-Fontaine MN, Rault J, van Oss CJ. Microbial adhesion to solvents: a novel 584 method to determine the electron-donor/electron-acceptor or Lewis acid-base properties of 585 microbial cells. Colloids Surf B 1996; 7:47-53. 
587 [40] Rijnaarts H, Norde W, Lyklema J, Zehnder AJB. The isoelectric point of bacteria as an 588 indicator for the presence of cell surface polymers that inhibit adhesion. Colloids Surf B $589 \quad 1995 ; 4: 191-197$.

590

591 [41] Kinloch AJ. Adhesion and Adhesives: Science and Technology, Chapman and Hall, 592 London; 1987.

593

594 [42] Cordeiro AL, Pettit ME, Callow ME, Callow A, Werner C. Controlling the adhesion of 595 the diatom Navicula perminuta using poly(N-isopropylacrylamide-co-N-(1-phenylethyl 596 acrylamide) films. Biotechnol Lett 2010; 32:489-495.

597

598 [43] Khodse VB, Bhosle NB. Differences in carbohydrate profiles in batch culture grown 599 planktonic and biofilm cells of Amphora rostrata Wm. Sm. Biofouling 2010; 26:527-537.

600 
601 Figure Legends

602

603 Figure 1: Scanning electron micrographs of Navicula jeffreyi. White arrow highlights the 604 bound EPS.

605

606 Figure 2: Kinetic study of the adhesion of Navicula jeffreyi on five different substrata (Glass,

607 PTFE, PE, PA and SS316; see Materials and Methods).

608

609 Figure 3: The values of the total interfacial free energy of adhesion of $N$. jeffreyi to the five 610 studied substrata and its components are given. Total $\left(\Delta G_{a d h}^{\text {Total }}\right.$, black dots), acid/base $\left(\Delta G_{a d h}^{A B}\right.$, 611 grey dots) and Lifshitz van der Waals ( $\Delta G_{a d h}^{L W}$, empty dots) interfacial free energy of adhesion 612 of Navicula jeffreyi on five different substrata.

613 
614 Figure 1

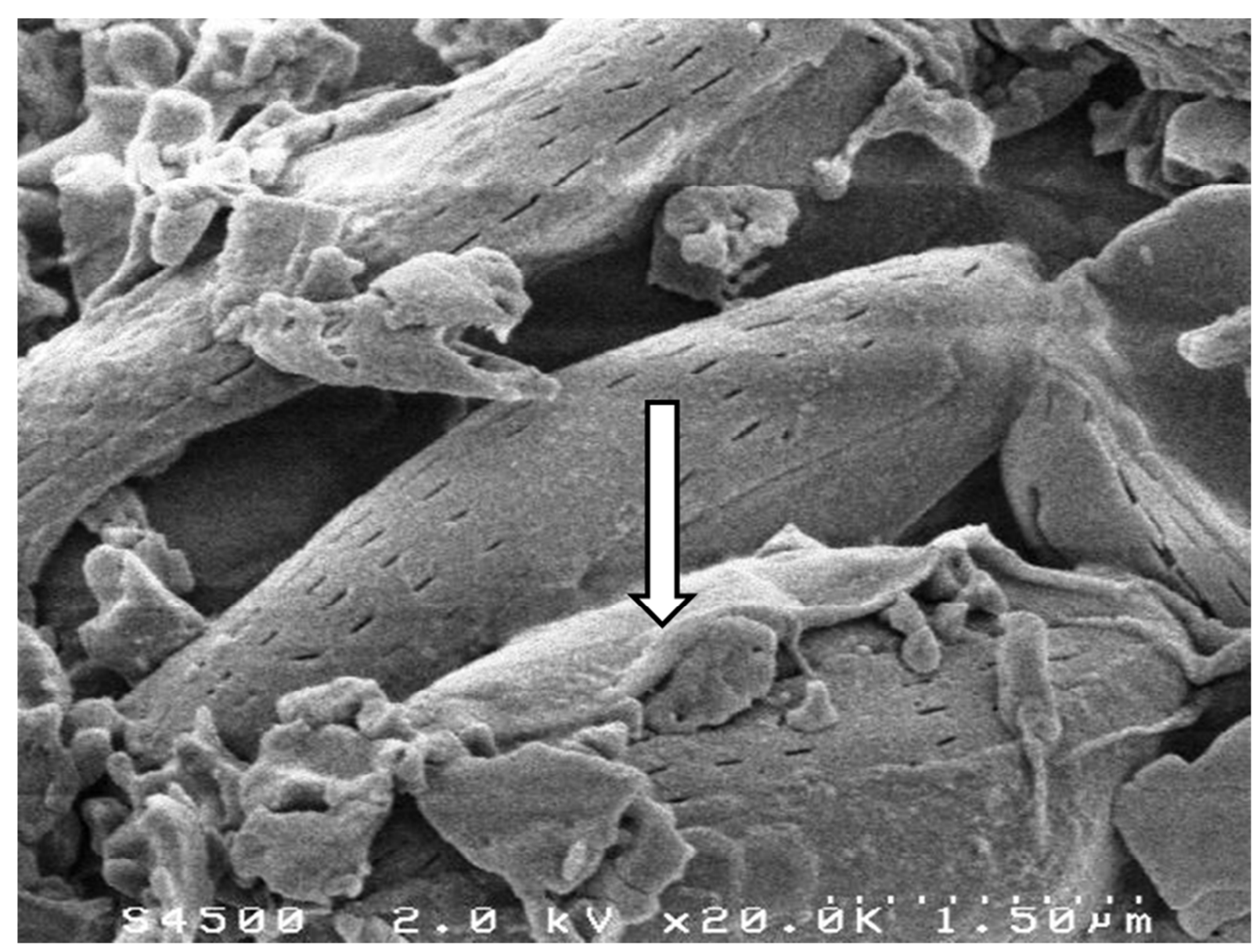


$616 \quad$ Figure 2

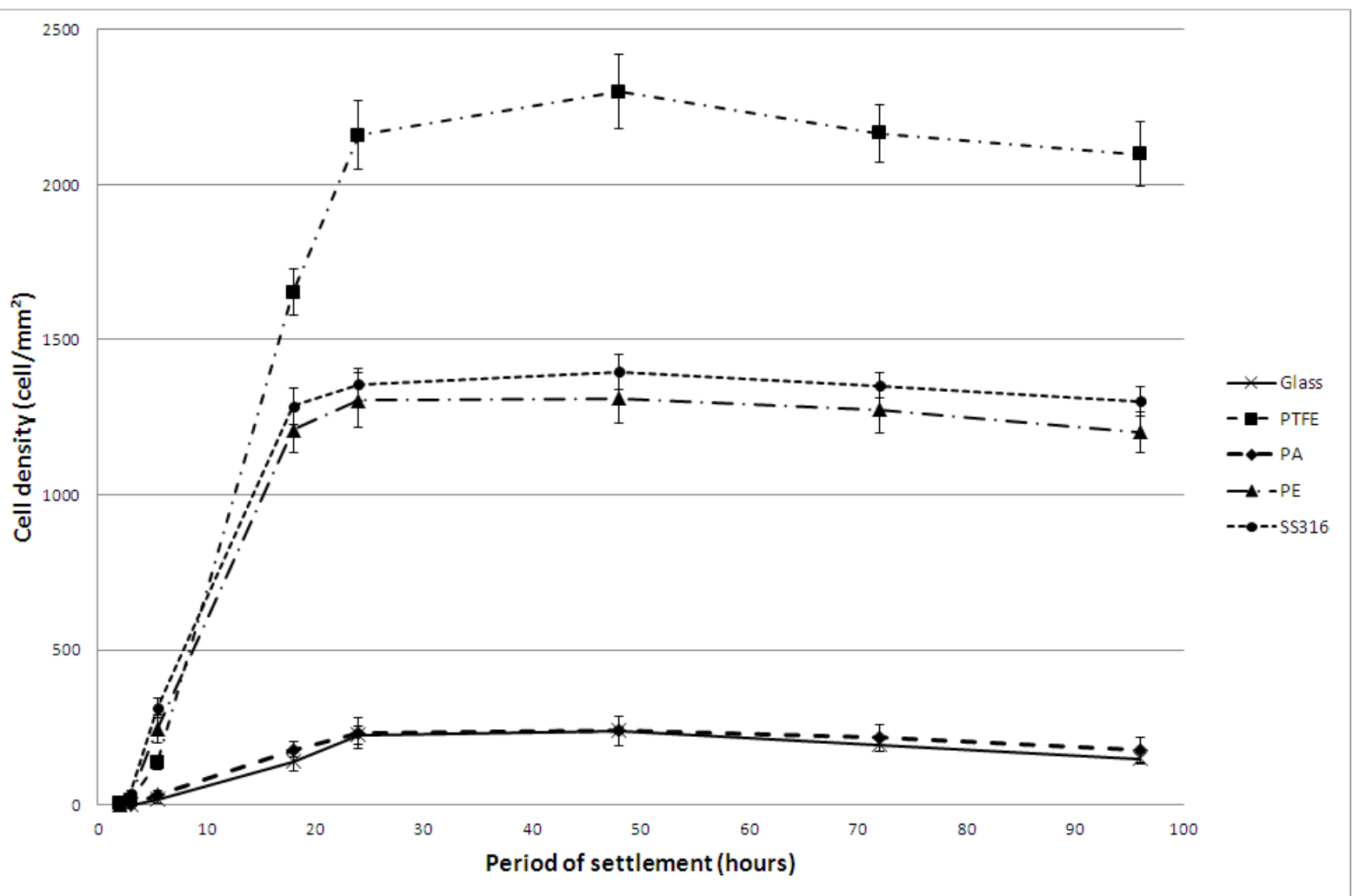


$618 \quad$ Figure 3

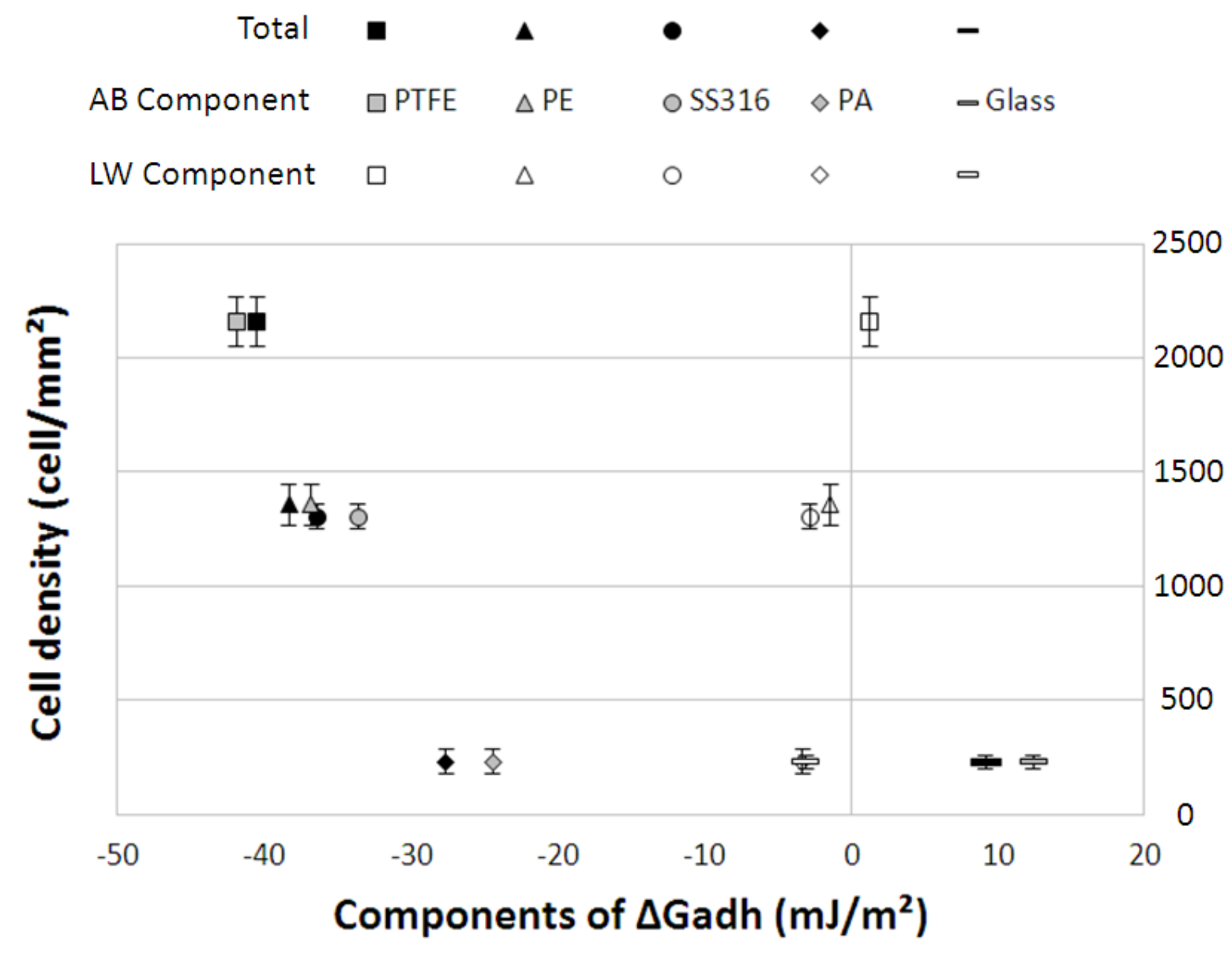


620 Table 1: Surface tension components of the different test solvents used in the contact angle

621 measurements: total $\left(\gamma^{\mathrm{t}}\right)$, Lifshitz-van der Walls $\left(\gamma^{\mathrm{LW}}\right)$, electron-acceptor $\left(\gamma^{+}\right)$and electron 622 donor $\left(\gamma^{-}\right)$components.

623

\begin{tabular}{lccccc}
\hline \multirow{2}{*}{ Test liquids } & Purity & \multicolumn{5}{c}{ Surface energy $\left(\mathbf{m J} / \mathbf{m}^{2}\right)$} \\
\cline { 3 - 6 } & & $\gamma_{L}^{t}$ & $\gamma_{L}^{L W}$ & $\gamma_{L}^{+}$ & $\gamma_{L}^{-}$ \\
\hline Water & MilliQ & 72.8 & 21.8 & 25.0 & 25.0 \\
Diiodomethane & $>98 \%$ & 50.8 & 50.8 & 0.0 & 0.0 \\
Formamide & $>99 \%$ & 58.0 & 35.6 & 2.3 & 39.6 \\
\hline
\end{tabular}

624 
625 Table 2: Monosaccharide composition (\% w/w) of polysaccharidic fraction of bound EPS 626 from cultures of $N$. jeffreyi (end of the exponential growth phase), after extraction through 627 Dowex-resin, with and without a freeze-drying step before extraction. Values are mean \pm SD 628 of three samples from a culture of $N$. jeffreyi, the variability within true sample replicates of 629 the biochemical analysis was less than 5\%.

630

Monosaccharide

with freeze-drying

without freeze-drying

Galacturonic acid

$17 \pm 3$

$15 \pm 4$

Sulfated sugars

$0 \pm 0.2$

$0 \pm 0.3$

Neutral sugars

$83 \pm 8.9$

$85 \pm 10.7$

Glucose

$36.1 \pm 4$

$34.5 \pm 3$

Rhamnose

$8.9 \pm 0.9$

$11.2 \pm 3$

Mannose

$18.4 \pm 2.1$

$21.3 \pm 4.1$

Galactose

$19.5 \pm 1.7$

$17.9 \pm 0.8$

631

632 
633 Table 3: Contact angle measurements of Stainless Steel AISI 316L (SS316), 634 Polytetrafluoroethylene (PTFE), Polyamide-nylon 6 (PA) and Polyethylene (PE), Glass, 635 membrane filters alone and Navicula jeffreyi layers previously deposited on cellulose 636 triacetate membrane filters. The results presented are the average of at least 8 measurements 637 done with each probe liquid for each surface, cell layer or solid substrata.

638

\begin{tabular}{|c|c|c|c|}
\hline \multirow{2}{*}{ Sample } & \multicolumn{3}{|c|}{ Contact angle $\left({ }^{\circ}\right)$} \\
\hline & Water & Diiodomethane & Formamide \\
\hline SS316 & $78.7 \pm 0.7$ & $44.5 \pm 1$ & $53.6 \pm 0.6$ \\
\hline PTFE & $110.9 \pm 2.0$ & $83.2 \pm 1.2$ & $99.4 \pm 1$ \\
\hline PA & $70.9 \pm 2.5$ & $38.5 \pm 1.5$ & $52.4 \pm 1.9$ \\
\hline PE & $99.7 \pm 4$ & $85.7 \pm 1.5$ & $58.7 \pm 2.7$ \\
\hline Glass & $10 \pm 1.6$ & $40.5 \pm 3$ & $10 \pm 0.1$ \\
\hline Membrane Filter & $56.2 \pm 1.8$ & $44.0 \pm 0.5$ & $49.9 \pm 1.7$ \\
\hline Navicula jeffreyi & $68.6 \pm 2.9$ & $54.3 \pm 2.1$ & $56.2 \pm 6.1$ \\
\hline
\end{tabular}

639

640 
641 Table 4: Surface energy of membrane filters alone, Navicula jeffreyi layers previously

642 deposited on cellulose triacetate membrane filters, the five selected substrata calculated from 643 equation (1) and cell density mean values measured on ten different fields for the five 644 substrata.

645

646

\begin{tabular}{|c|c|c|c|c|c|c|}
\hline \multirow{2}{*}{ Sample } & \multicolumn{5}{|c|}{ Surface energy $\left(\mathrm{mJ} / \mathrm{m}^{2}\right)$} & \multirow{2}{*}{$\begin{array}{l}\text { Cell density } \\
\text { (cell.mm²) }\end{array}$} \\
\hline & $\gamma^{t}$ & $\gamma^{L W}$ & $\gamma^{A B}$ & $\gamma^{+}$ & $\gamma^{-}$ & \\
\hline $\begin{array}{l}\text { Membrane } \\
\text { Filter }\end{array}$ & $39.8 \pm 1.0$ & $37.5 \pm 0.3$ & $2.2 \pm 3.4$ & $0.1 \pm 0.1$ & $28.6 \pm 1.2$ & \\
\hline $\begin{array}{l}\text { Navicula } \\
\text { jeffreyi }\end{array}$ & $36.7 \pm 4.1$ & $31.8 \pm 1.1$ & $4.8 \pm 2.9$ & $0.4 \pm 0.1$ & $16.1 \pm 2.1$ & \\
\hline PTFE & $17.1 \pm 0.6$ & $15.9 \pm 0.6$ & $1.2 \pm 0.3$ & $0.2 \pm 0.1$ & $1.9 \pm 0.5$ & $2160 \pm 110$ \\
\hline PE & $32.5 \pm 2.7$ & $29.3 \pm 1.5$ & $3.2 \pm 1.2$ & $0.8 \pm 0.3$ & $3.4 \pm 1.6$ & $1356 \pm 88$ \\
\hline SS316 & $40.6 \pm 0.4$ & $37.3 \pm 0.8$ & $3.3 \pm 0.3$ & $0.6 \pm 0.1$ & $5.0 \pm 0.6$ & $1305 \pm 52$ \\
\hline PA & $42.4 \pm 0.9$ & $40.4 \pm 0.8$ & $2.0 \pm 0.2$ & $0.1 \pm 0.0$ & $11.5 \pm 1.5$ & $231 \pm 51$ \\
\hline Glass & $56.2 \pm 0.3$ & $39.3 \pm 1.6$ & $16.8 \pm 1.9$ & $1.3 \pm 0.3$ & $54.1 \pm 0.2$ & $225 \pm 29$ \\
\hline
\end{tabular}

647

648 